\title{
Nocardia polyresistens sp. nov.
}

\author{
Correspondence \\ Wen-Jun Li \\ wjli@ynu.edu.cn
}

\author{
Ping $\mathrm{Xu},{ }^{1,2} \dagger$ Wen-Jun $\mathrm{Li}^{1}{ }^{1} \dagger$ Shu-Kun Tang, ${ }^{1} \mathrm{Yi}_{\mathrm{i}}$ Jiang, ${ }^{1}$ Hua-Hong Chen, \\ Li-Hua $\mathrm{Xu}^{1}$ and Cheng-Lin Jiang ${ }^{1}$
}

\author{
${ }^{1}$ The Key Laboratory for Microbial Resources of Ministry of Education, Yunnan Institute of \\ Microbiology, Yunnan University, Kunming, Yunnan, 650091, P. R. China \\ ${ }^{2}$ New Drug R \& D, North China Pharmaceutic Corp., Shijiazhuang, 050015, P. R. China
}

The application of chemotaxonomic, numerical phenetic and molecular systematic methods has promoted a radical reappraisal of the genus Nocardia (Goodfellow, 1998; Goodfellow et al., 1999; Lechevalier, 1976). This improved classification provides a sound framework for the recognition of additional species (Yassin et al., 2001). Members of the genus form extensively branched mycelia and the substrate hyphae fragment into rod-shaped, non-motile elements; aerial hyphae are usually formed but are sometimes only visible microscopically (Goodfellow \& Lechevalier, 1989; Gordon \& Mihm, 1957, 1962). Nocardiae are also characterized by a number of chemical markers, including the presence of meso-diaminopimelic acid (DAP), arabinose and galactose, mycolic acids and a DNA G $+\mathrm{C}$ content of 64-72\% (Goodfellow \& Lechevalier, 1989; Goodfellow, 1992).

Currently, the genus Nocardia encompasses 54 accepted species with validly published names. Much of the emphasis in nocardial systematics has focused on the causal agents of actinomycetoma and nocardiosis (Goodfellow, 1992, 1998; McNeil \& Brown, 1994). Little is known about nocardial species diversity, functional activities and commercial value in natural habitats (Kämpfer et al., 2004; Maldonado et al., 2000; Orchard et al., 1977; Orchard \& Goodfellow, 1980; Saintpierre-Bonaccio et al., 2004; Wang et al., 2001; Zhang et al., 2003). In the course of our screening programme for new antibiotics, several actinomycete strains, which contained both type I and type II polyketide biosynthetic

Published online ahead of print on 28 January 2005 as DOI 10.1099/ ijs.0.63352-0.

†These authors contributed equally to this work.

Abbreviation: DAP, diaminopimelic acid.

The GenBank/EMBL/DDBJ accession number for the 16S rRNA gene

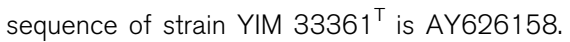

pathway genes, were isolated from soil samples collected from Yunnan Province, China (Xu et al., 2003a).

Strain YIM $33361^{\mathrm{T}}$ was isolated from a soil sample after 2 weeks incubation at $28^{\circ} \mathrm{C}$ on water/proline $(1 \%$ proline in tap water) agar. Biomass for molecular systematic and most of the chemotaxonomic studies was obtained after incubation at $28^{\circ} \mathrm{C}$ for 7 days by growing in shake flasks of yeast extract-malt extract broth (ISP 2 broth; Shirling \& Gottlieb, 1966) supplemented with the vitamin mixture of HV medium (Hayakawa \& Nonomura, 1987). Cultural characteristics were determined after 2 weeks at $28^{\circ} \mathrm{C}$ by methods used in the International Streptomyces Project (ISP; Shirling \& Gottlieb, 1966) except for modified Sauton's agar (Mordarska et al., 1972). Morphological observations of spores and mycelia were made by light microscopy (Olympus microscope $\mathrm{BH}-2$ ) and scanning electron microscopy (model JEOL JSM 5600LV). Gram (Hucker's modification; Society for American Bacteriologists, 1957) and Ziehl-Neelsen (Gordon, 1967) preparations were also observed by light microscopy.

The test strain was examined for a range of phenotypic properties using standard procedures (Goodfellow, 1971; Williams et al., 1983). In addition, acid production from carbohydrates was carried out using media and methods described by Gordon et al. (1974). The utilization of sole carbon and sole nitrogen sources was investigated after Gordon \& Mihm (1957) and Tsukamura (1966). Resistance to lysozyme was determined by the method of Gordon et al. (1974). Tolerance to temperature (10, 27, 30, 37 and $\left.45^{\circ} \mathrm{C}\right)$, sodium chloride $(4,7,10$ and $13 \%)$ and phenol $(0 \cdot 1$, $0 \cdot 2,0.5$ and $1 \cdot 0 \%)$ was tested using modified Bennett's agar (Williams et al., 1983). Resistance to antibiotics was examined using amikacin $(30 \mu \mathrm{g})$, aureomycin $(30 \mu \mathrm{g})$, ciprofloxacin $(10 \mu \mathrm{g})$, chloramphenicol $(30 \mu \mathrm{g})$, erythromycin $(15 \mu \mathrm{g})$, gentamicin sulfate $(10 \mu \mathrm{g})$, kanamycin $(15 \mu \mathrm{g})$, netilmicin $(10 \mu \mathrm{g})$, novobiocin $(30 \mu \mathrm{g})$, oleandomycin 
$(10 \mu \mathrm{g})$, penicillin $\mathrm{G}(10 \mathrm{U})$, polymyxin $\mathrm{B}(300 \mathrm{U})$, streptomycin sulfate $(10 \mu \mathrm{g})$, terramycin $(30 \mu \mathrm{g})$, tetracycline $(30 \mu \mathrm{g})$, tobramycin sulfate $(10 \mu \mathrm{g})$ and vancomycin $(10 \mu \mathrm{g})$ discs (Goodfellow \& Orchard, 1974) with glucoseyeast extract agar (Gordon \& Mihm, 1962) as the basal medium; the results were recorded following incubation at $28^{\circ} \mathrm{C}$ for up to 14 days. Colours and hues were determined according to Kelly (1964).

Cell wells were purified and amino acids of peptidoglycan were analysed by TLC (Lechevalier \& Lechevalier, 1980; Jiang et al., 2001). Analysis of whole-cell sugar composition followed procedures described by Becker et al. (1965) and Lechevalier \& Lechevalier (1980). Phospholipid analysis was carried out as described by Lechevalier et al. (1981). The acid methanolysis procedure was used to detect mycolic acids (Minnikin et al., 1975). Menaquinones were determined using the procedures of Collins et al. (1977). Biomass for the quantitative fatty acid analysis was prepared by scraping growth from TSA plates [trypticase soy broth (BBL), $3 \%(\mathrm{w} / \mathrm{v})$; Bacto agar (Difco), $1 \cdot 5 \%(\mathrm{w} / \mathrm{v})]$ that had been incubated for 3 days at $28^{\circ} \mathrm{C}$. The fatty acids were extracted, methylated and analysed using the standard MIDI (Microbial Identification) system (Sasser, 1990; Kämpfer \& Kroppenstedt, 1996).

Genomic DNA extraction and PCR amplification of the 16S rRNA gene from strain YIM $33361^{\mathrm{T}}$ were carried out using procedures described by Xu et al. (2003b). The nearly complete resultant 16S rRNA gene sequence (1511 nucleotides) was aligned manually with corresponding almostcomplete sequences of representative Nocardia species retrieved from the DDBJ, EMBL and GenBank databases by using BLAST (Altschul et al., 1997) and BLAST 2 sequences (Tatusova \& Madden, 1999). Phylogenetic analysis was performed using the software packages PHYLIP (Felsenstein, 1993) and MEGA version 2.1 (Kumar et al., 2001) after multiple alignment of data by CLUSTAL X (Thompson et al., 1997); distances (distance options) according to the Kimura two-parameter model (Kimura, 1980, 1983) and clustering with the neighbour-joining method (Saitou \& Nei, 1987).
The topology of the tree was evaluated by performing a bootstrap analysis (Felsenstein, 1985) using 1000 resamplings. Arthrobacter globiformis was used as the outgroup.

The chromosomal DNA for genomic DNA G + C content analysis was extracted as described by Marmur (1961). The DNA G $+C$ base content of strain YIM $33361^{\mathrm{T}}$ was determined by the thermal denaturation method (Mandel \& Marmur, 1968).

Strain YIM $33361^{\mathrm{T}}$ has phenotypic properties consistent with its classification in the genus Nocardia (Goodfellow et al., 1999). The organism is aerobic, Gram-positive, slightly acid-alcohol-fast. It developed well on several media including ISP 2 agar, glycerol-asparagine agar (ISP 5 medium; Shirling \& Gottlieb, 1966), potato agar (DSMZ medium 129) and modified Bennett's agar (Jones, 1949), showed moderate growth on oatmeal agar (ISP 3 medium; Shirling \& Gottlieb, 1966), inorganic salts-starch agar (ISP 4 medium; Shirling \& Gottlieb, 1966), modified Sauton's agar (Mordarska et al., 1972) and nutrient agar (Waksman, 1961) and grew poorly on Czapek's agar (Shirling \& Gottlieb, 1966) (Table 1). Diffusible pigments were not produced on any tested medium. Morphological features were observed on modified Bennett's agar. The substrate mycelium branched extensively and fragmented into nonmotile, rod-shaped elements. The white aerial mycelium was also well developed. Sporotrichetes of up to seven spores were borne on both substrate and aerial hyphae.

Whole-organism hydrolysates of strain YIM $33361^{\mathrm{T}}$ were rich in meso-DAP, arabinose and galactose (cell wall chemotype IV sensu Lechevalier \& Lechevalier, 1970) and diphosphatidylglycerol, phosphatidylethanolamine, phosphatidylinositol and phosphatidylinositol mannosides (phospholipid type II sensu Lechevalier et al., 1977). The menaquinones were $\mathrm{MK}-8\left(\mathrm{H}_{4} \omega\right.$-cycl. $)(85 \%)$ and MK$8\left(\mathrm{H}_{2}\right)(15 \%)$. It was also characterized by the presence of mycolic acids that co-migrated $\left(\mathrm{R}_{\mathrm{f}}\right.$ value around $\left.0 \cdot 47\right)$ with those from marker strains of Nocardia. The fatty acid profile contained mainly straight-chain saturated, unsaturated and 10-methyl-branched fatty acids. The predominant

Table 1. Cultural characteristics of strain $\mathrm{YIM} 33361^{\top}$ on various media

Colours were determined according to Kelly (1964).

\begin{tabular}{|llll|}
\hline Medium & Growth & Aerial mycelium & Substrate mycelium \\
\hline Yeast extract-malt extract (ISP 2) & Good & White & Moderate orange-yellow \\
Oatmeal agar (ISP 3) & Moderate & - & Yellow-white \\
Inorganic salts-starch agar (ISP 4) & Moderate & Yellow-white & Yellow-white \\
Glycerol-asparagine agar (ISP 5) & Good & Pale yellow & Pale yellow \\
Czapek's agar & Poor & White & Yellow-white \\
Modified Sauton's agar & Moderate & White & Pale yellow \\
Modified Bennett's agar & Good & White & Pale yellow \\
Potato agar & Good & White & Pale yellow \\
Nutrient agar & Moderate & White & Light yellow \\
\hline
\end{tabular}


Table 2. Phenotypic properties that separate strain YIM $33361^{\top}$ from related Nocardia species

Data were taken from this and previous studies (Maldonado et al., 2000; Wang et al., 2001; Zhang et al., 2003; Yassin et al., 2001; Albuquerque de Barros et al., 2003; Kämpfer et al., 2004; Saintpierre-Bonaccio et al., 2004; Kageyama et al., 2004a, b). Symbols: +, utilization; -, no utilization; D, doubtful; w, weak; ND, not determined.

\begin{tabular}{|c|c|c|c|c|c|c|c|c|c|c|c|c|c|c|c|c|}
\hline \multirow[t]{2}{*}{ Strain } & \multicolumn{3}{|c|}{ Hydrolysis of: } & \multirow{2}{*}{$\begin{array}{l}\text { Nitrate } \\
\text { reduction }\end{array}$} & \multicolumn{6}{|c|}{ Decomposition of $(\%, w / v)$ : } & \multicolumn{5}{|c|}{ Growth on sole carbon sources $(\%, w / v)$} & \multirow{2}{*}{$\begin{array}{r}\text { Growth } \\
\text { - at } 45^{\circ} \mathrm{C}\end{array}$} \\
\hline & Aesculin & Arbutin & Urea & & $\begin{array}{l}\text { Adenine } \\
(0 \cdot 4)\end{array}$ & $\begin{array}{c}\text { Casein } \\
(1 \cdot 0)\end{array}$ & $\begin{array}{c}\text { Elastin } \\
(0 \cdot 3)\end{array}$ & $\begin{array}{l}\text { Hypoxanthine } \\
(0 \cdot 4)\end{array}$ & $\begin{array}{c}\text { Tyrosine } \\
(0 \cdot 5)\end{array}$ & $\begin{array}{c}\text { e Xanthine } \\
(0 \cdot 4)\end{array}$ & $\mathrm{D}(+)$-Mannitol & $\begin{array}{c}\text { L-Rhamnose } \\
(\mathbf{1} \cdot \mathbf{0})\end{array}$ & $\begin{array}{c}\mathrm{D}(+) \text {-Sorbitol } \\
(1 \cdot 0)\end{array}$ & $\begin{array}{l}1 \quad \text { Sodium } \\
\text { acetate }(0 \cdot 1)\end{array}$ & $\begin{array}{c}\text { Sodium } \\
\text { citrate }(0 \cdot 1)\end{array}$ & \\
\hline N. caishijiensis $\mathrm{F} 829^{\mathrm{T}}$ & - & - & + & + & - & - & - & - & - & - & - & + & - & + & - & - \\
\hline N. abscessus DSM $44432^{\mathrm{T}}$ & - & + & + & + & - & - & - & - & - & - & - & + & - & + & + & - \\
\hline N. africana DSM $44491^{\mathrm{T}}$ & - & - & - & + & - & + & - & - & - & - & - & - & - & - & - & + \\
\hline N. asteroides ATCC $19247^{\mathrm{T}}$ & + & + & + & + & - & - & - & - & - & - & + & - & - & + & + & - \\
\hline N. beijingensis JCM $10666^{\mathrm{T}}$ & + & - & + & + & - & - & - & - & - & + & + & + & + & + & + & - \\
\hline N. brasiliensis ATCC $19296^{\mathrm{T}}$ & + & + & + & + & - & + & + & + & + & - & + & - & - & + & + & + \\
\hline N. brevicatena DSM $43024^{\mathrm{T}}$ & + & + & - & - & - & - & - & - & - & - & - & + & - & + & - & - \\
\hline N. carnea DSM $43397^{\mathrm{T}}$ & + & - & - & + & - & - & - & - & - & - & + & - & + & + & - & - \\
\hline N. cerradoensis $\mathrm{Y}^{\mathrm{T}}$ & + & ND & + & + & - & - & - & - & - & - & - & + & + & + & - & - \\
\hline N. crassostreae ATCC $700418^{\mathrm{T}}$ & + & $\mathrm{ND}$ & - & - & - & - & - & - & - & - & - & + & - & - & - & - \\
\hline N. cummidelens DSM $44490^{\mathrm{T}}$ & + & + & + & + & - & - & - & - & - & - & - & - & - & + & - & - \\
\hline N. cyriacigeorgica DSM $44484^{\mathrm{T}}$ & + & $\mathrm{ND}$ & + & $\mathrm{ND}$ & - & - & - & - & - & - & - & - & - & + & - & - \\
\hline N. farcinica ATCC $3318^{\mathrm{T}}$ & + & + & + & + & - & - & - & - & - & - & - & + & - & + & - & + \\
\hline N. flavorosea $\mathrm{JCM} 3332^{\mathrm{T}}$ & - & + & - & - & - & - & - & - & - & - & + & - & + & + & + & - \\
\hline N. fluminea DSM $44489^{\mathrm{T}}$ & + & + & - & + & - & - & - & - & + & - & - & + & - & - & + & - \\
\hline N. ignorata DSM $44496^{\mathrm{T}}$ & + & $\mathrm{ND}$ & $\mathrm{ND}$ & ND & ND & - & - & - & - & - & + & - & $\mathrm{ND}$ & + & - & + \\
\hline N. nova JCM $6044^{\mathrm{T}}$ & + & + & + & + & - & - & - & - & - & - & + & - & + & + & - & - \\
\hline N. otitidiscaviarum NCTC $1934^{\mathrm{T}}$ & + & + & + & + & - & - & - & + & - & + & + & - & - & + & - & + \\
\hline N. paucivorans DSM $44386^{\mathrm{T}}$ & - & + & + & + & - & - & - & - & - & - & - & - & - & + & - & - \\
\hline N. pseudobrasiliensis ATCC $51512^{\mathrm{T}}$ & + & - & + & - & + & + & + & + & + & - & + & - & + & + & + & - \\
\hline N. salmonicida JCM $4826^{\mathrm{T}}$ & + & + & + & + & - & - & - & - & + & + & + & - & + & + & + & - \\
\hline N. seriolae JCM $3360^{\mathrm{T}}$ & + & + & - & + & - & - & - & - & - & - & - & - & - & + & + & - \\
\hline N. soli DSM $44488^{\mathrm{T}}$ & + & + & + & + & - & - & - & - & - & - & - & + & - & + & - & - \\
\hline N. transvalensis DSM $43405^{\mathrm{T}}$ & + & + & + & + & - & - & + & + & - & - & + & + & + & + & - & - \\
\hline N. uniformis JCM $3224^{\mathrm{T}}$ & + & + & + & + & - & - & + & + & + & + & - & - & - & + & - & - \\
\hline N. vaccinii DSM $43285^{\mathrm{T}}$ & + & - & + & + & - & - & - & - & - & - & + & + & - & - & - & - \\
\hline N. veterana DSM $44445^{\mathrm{T}}$ & $\mathrm{D}$ & ND & + & - & - & - & - & - & - & - & - & + & - & - & - & + \\
\hline N. vinacea JCM $10988^{\mathrm{T}}$ & $\mathrm{D}$ & ND & + & + & - & - & - & + & - & - & + & - & + & ND & $\mathrm{D}$ & - \\
\hline N. neocaledoniensis $\mathrm{SBH}_{\mathrm{R}} \mathrm{OA6}^{\mathrm{T}}$ & + & ND & + & + & - & - & - & - & + & - & + & - & - & - & - & + \\
\hline N. tenerifensis DSM $44704^{\mathrm{T}}$ & + & ND & + & ND & - & + & ND & + & + & - & + & - & - & $\mathrm{ND}$ & + & - \\
\hline N. asiatica IFM $0245^{\mathrm{T}}$ & + & + & $\mathrm{D}$ & + & - & - & - & - & - & - & $\mathrm{D}$ & + & - & + & + & - \\
\hline N. inohanensis IFM $0092^{\mathrm{T}}$ & $\mathrm{ND}$ & $\mathrm{ND}$ & + & ND & - & - & ND & + & - & - & ND & - & - & ND & + & - \\
\hline N. yamanashiensis IFM $0265^{\mathrm{T}}$ & ND & ND & + & ND & - & - & ND & + & - & - & ND & - & - & ND & + & - \\
\hline N. niigatensis IFM $0330^{\mathrm{T}}$ & ND & $\mathrm{ND}$ & $\mathrm{D}$ & ND & - & - & ND & $\mathrm{w}$ & - & - & ND & - & - & $\mathrm{ND}$ & - & - \\
\hline YIM $33361^{\mathrm{T}}$ & - & ND & + & - & - & $\mathrm{D}$ & + & + & $\mathrm{D}$ & + & + & - & - & - & - & - \\
\hline
\end{tabular}


components, as a proportion of the total fatty acid composition, were $\mathrm{i}_{-} \mathrm{C}_{15: 0}(1 \cdot 33 \%)$, ai- $\mathrm{C}_{15: 0}(5 \cdot 73 \%), \mathrm{i}-\mathrm{C}_{16: 0}$ $(1 \cdot 76 \%)$, cis7- $\mathrm{C}_{16: 1}(1 \cdot 33 \%), \mathrm{i}-2-\mathrm{OH}-\mathrm{C}_{15: 0}(5 \cdot 69 \%), \mathrm{C}_{16: 0}$ $(22 \cdot 14 \%)$, i-C $17: 0 \quad(2 \cdot 16 \%), \quad$ ai- $\mathrm{C}_{17: 0} \quad(2 \cdot 72 \%), \mathrm{C}_{17: 0}$ $(1 \cdot 53 \%)$, cis6,9-C $18: 2 \quad(10 \cdot 86 \%)$, cis $9-\mathrm{C}_{18: 1} \quad(10 \cdot 05 \%)$, $\mathrm{C}_{18: 0}(21 \cdot 16 \%)$ and 10 -methyl-C $18: 0(10 \cdot 5 \%)$. The G+C content of genomic DNA was $65 \cdot 6$ mol\%. Detailed results of the physiological features are indicated in Table 2 and in the species description.

A database search demonstrated that the strain YIM $33361^{\mathrm{T}}$ belongs to the family Nocardiaceae (Stackebrandt et al., 1997) and that the determined sequence contains all the signature nucleotides characteristic of the genus Nocardia (Chun \& Goodfellow, 1995). The rooted phylogenetic tree (Fig. 1) indicated that strain YIM $33361^{\mathrm{T}}$ formed a distinct subclade within the genus Nocardia. Low 16S rRNA gene sequence similarity values $(<97 \%)$ were found with all

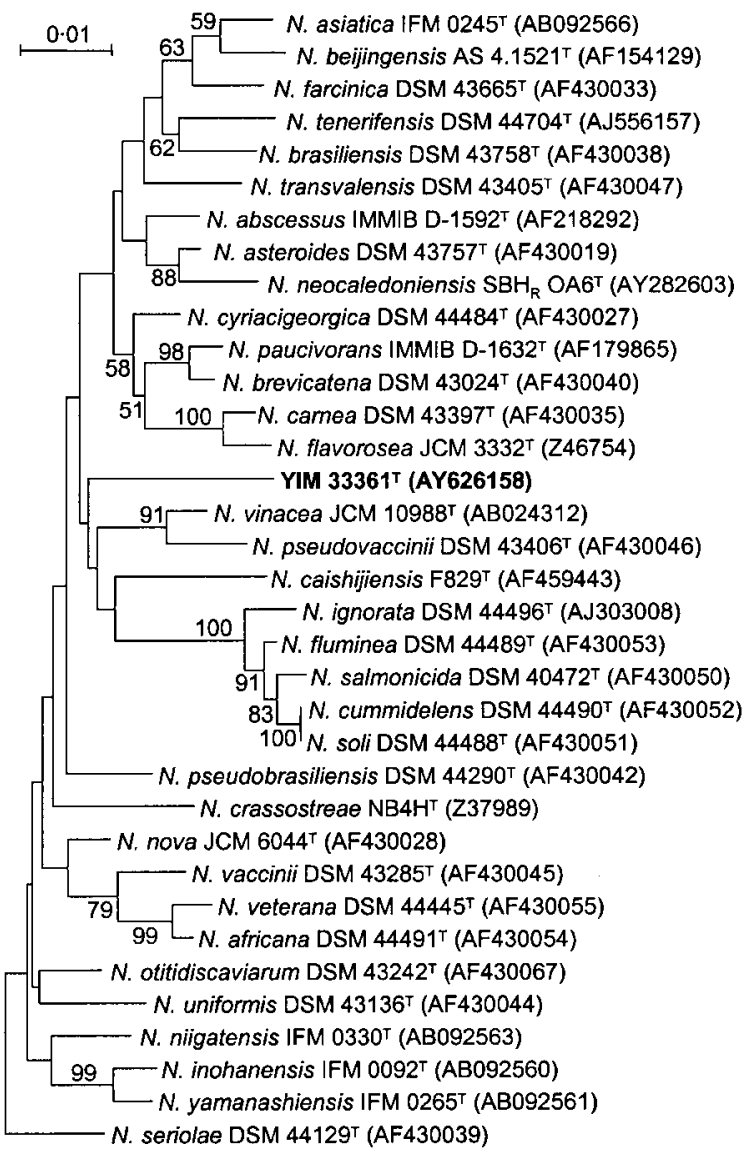

Fig. 1. Phylogenetic dendrogram obtained by neighbour-joining analysis based on $1396 \mathrm{bp}$ of $16 \mathrm{~S}$ rRNA gene sequences, showing the position of strain $\mathrm{YIM} 33361^{\top}$ among its phylogenetic neighbours. Numbers on branch nodes are bootstrap percentages (1000 resamplings). Sequence accession numbers are given in parentheses. The sequence of Arthrobacter globiformis DSM 20124 ${ }^{\top}$ (X80736) was used as the root (not shown). Bar, 0.01 substitutions per nucleotide position. species with validly published names of the genus Nocardia. The closest relatives of strain YIM $33361^{\mathrm{T}}$ were Nocardia pseudobrasiliensis DSM 44290 ${ }^{\mathrm{T}}$ (AF430042) and Nocardia paucivorans DSM 44386 ${ }^{\mathrm{T}}$ (AF430041) which both showed $96.92 \%$ similarity (46 nucleotide differences in 1492 sites).

This is also supported by phenotypic data, as at least three differences in phenotypic properties were observed between strain YIM $33361^{\mathrm{T}}$ and the species with validly published names of the genus Nocardia (Table 2). Strain YIM $33361^{\mathrm{T}}$, N. paucivorans IMMIB D-1632 ${ }^{\mathrm{T}}$ and N. pseudobrasiliensis ATCC $51512^{\mathrm{T}}$ can also be distinguished easily by their physiological properties. Each of the two strains shows seven differences in comparison with the characteristics of strain YIM $33361^{\mathrm{T}}$ (Table 2).

In conclusion, the genotypic and phenotypic data show that strain YIM $33361^{\mathrm{T}}$ forms a novel species of the genus Nocardia, for which we propose the name Nocardia polyresistens sp. nov.

\section{Description of Nocardia polyresistens sp. nov.}

Nocardia polyresistens [poly.re.sis'tens. Gr. adj. polus many; L. part. adj. resistens resisting; N.L. part. adj. polyresistens resisting many (antibiotics)].

Aerobic, Gram-positive, catalase-positive and slightly acidalcohol-fast. Aerial mycelium and substrate mycelium are extensively branched and fragment irregularly into rodshaped, non-motile elements. A pale-yellow to moderate orange-yellow substrate mycelium carries sparse to abundant, white aerial hyphae on yeast extract-malt extract agar, Czapek's agar, modified Sauton's agar, modified Bennett's agar, potato agar and nutrient agar. A pale-yellow to yellowwhite substrate mycelium bears pale-yellow to yellowwhite aerial hyphae on glycerol-asparagine or inorganic salts-starch agar. Diffusible pigments are not formed. Ribose, glucose, mannose, fructose, sorbose, melibiose, xylose, sucrose, arabinose, galactose, maltose, lactose, cellobiose, raffinose, melezitose, mannitol, inositol, xylitol, dulcitol, adonitol, salicin, glycerol and dextrin are utilized as sole carbon and energy sources, but not rhamnose, trehalose, sorbitol, arabitol, acetate, malonate, citrate, oxalate or tartrate. Acid is not formed from these tested carbon sources. L-Valine, L-proline (weak), L-asparagine, L-tyrosine (weak), L-alanine and L-histidine are used as sole nitrogen sources, but not acetamide, L-hydroxyproline, Llysine, L-methionine, L-tryptophan, L-threonine, L-glutamic acid, glycine, L-arginine, L-cysteine or phenylalanine. Urea, xanthine, hypoxanthine, amygdalin, keratin and chitin are hydrolysed. Tweens 20 and 80 are degraded, but not cellulose, starch, allantoin, glucosamine, aesculin, DNA or adenine. Tests for gelatin hydrolysis, nitrate reduction, melanin production, milk coagulation and peptonization, $\mathrm{H}_{2} \mathrm{~S}$ production and resistance to $\mathrm{KCN}$ are negative. Grows between 28 and $37^{\circ} \mathrm{C}$, from $\mathrm{pH} 7$ to 9 , and in the presence of phenol at $0 \cdot 1 \%$, but not in the presence of sodium chloride. Resistant to lysozyme, penicillin G, ciprofloxacin, 
vancomycin, polymyxin B, erythromycin, terramycin, aureomycin (weak), tobramycin, gentamicin sulfate, amikacin, netilmicin, novobiocin, kanamycin and oleandomycin but sensitive to tetracycline, streptomycin and chloramphenicol. The cell wall of strain YIM $33361^{\mathrm{T}}$ contains meso-DAP. Whole-cell sugars are galactose and arabinose. MK- $8\left(\mathrm{H}_{4} \omega\right.$-cycl. $)$ is the major menaquinone and a minor amount of MK- $8\left(\mathrm{H}_{2}\right)$ is also present. The phospholipids are diphosphatidylglycerol, phosphatidylethanolamine, phosphatidylinositol and phosphatidylinositol mannosides. The major cellular fatty acids are $\mathrm{C}_{16: 0}$ $(22 \cdot 14 \%)$, cis6,9-C $\mathrm{C}_{18: 2}(10 \cdot 86 \%)$, cis $9-\mathrm{C}_{18: 1}(10 \cdot 05 \%)$, $\mathrm{C}_{18: 0}(21 \cdot 16 \%)$ and 10 -methyl- $\mathrm{C}_{18: 0}(10 \cdot 5 \%)$. The G+C content of genomic DNA of the type strain is $65 \cdot 6 \mathrm{~mol} \%$.

The type strain, YIM $33361^{\mathrm{T}}\left(=\right.$ CCTCC AA $204004^{\mathrm{T}}=$ KCTC $19027^{\mathrm{T}}$ ), was isolated from soil in Yunnan, China.

\section{Acknowledgements}

This research was supported by the National Basic Research Program of China (project no. 2004CB719601), the National Natural Science Foundation of China (project no. 30270004) and the Yunnan Provincial Natural Science Foundation (project no. 2004 C0002Q).

\section{References}

Albuquerque de Barros, E. V. S., Manfio, G. P., Ribeiro Maitan, V., Mendes Bataus, L. A., Kim, S. B., Maldonado, L. A. \& Goodfellow, M. (2003). Nocardia cerradoensis sp. nov., a novel isolate from Cerrado soil in Brazil. Int J Syst Evol Microbiol 53, 29-33.

Altschul, S. F., Madden, T. L., Schäffer, A. A., Zhang, J., Zhang, Z., Miller, W. \& Lipman, D. J. (1997). Gapped BLAST and PSI-BLAST: a new generation of protein database search programs. Nucleic Acids Res 25, 3389-3402.

Becker, B., Lechevalier, M. P. \& Lechevalier, H. A. (1965). Chemical composition of cell-wall preparation from strains of various formgenera of aerobic actinomycetes. Appl Microbiol 13, 236-243.

Chun, J. \& Goodfellow, M. (1995). A phylogenetic analysis of the genus Nocardia with $16 \mathrm{~S}$ rRNA gene sequences. Int J Syst Bacteriol 45, 240-245.

Collins, M. D., Pirouz, T., Goodfellow, M. \& Minnikin, D. E. (1977). Distribution of menaquinones in actinomycetes and corynebacteria. J Gen Microbiol 100, 221-230.

Felsenstein, J. (1985). Confidence limits on phylogenies: an approach using the bootstrap. Evolution 39, 783-791.

Felsenstein, J. (1993). PHYLIP - Phylogeny Inference Package, version 3.5c. Distributed by the author. Department of Genome Sciences, University of Washington, Seattle, USA.

Goodfellow, M. (1971). Numerical taxonomy of some nocardioform bacteria. J Gen Microbiol 69, 33-80.

Goodfellow, M. (1992). The family Nocardiaceae. In The Prokaryotes, 2nd edn, pp. 1188-1213. Edited by A. Balows, H. G. Trüper, M. Dworkin, W. Harder \& K. H. Schleifer. New York: Springer.

Goodfellow, M. (1998). Nocardia and related genera. In Topley and Wilson's Microbiology and Microbial Infections, 9th edn, vol. 2, Systematic Bacteriology, pp. 463-489. Edited by A. Balows \& B. I. Duerden. London: Arnold.

Goodfellow, M. \& Lechevalier, M. P. (1989). Genus Nocardia Trevisan 1889, $9^{\mathrm{AL}}$. In Bergey's Manual of Systematic Bacteriology, vol. 2, pp. 1458-1471. Edited by S. T. Williams, M. E. Sharpe \& J. G. Holt. Baltimore: Williams \& Wilkins.

Goodfellow, M. \& Orchard, V. A. (1974). Antibiotic sensitivity of some nocardioform bacteria and its value as a criterion for taxonomy. J Gen Microbiol 83, 375-387.

Goodfellow, M., Isik, K. \& Yates, E. (1999). Actinomycete systematics: an unfinished synthesis. Nova Acta Leopold NF80(312), 47-82.

Gordon, R. E. (1967). The taxonomy of soil bacteria. In The Ecology of Soil Bacteria, pp. 293-321. Edited by T. R. G. Gray \& D. Parkinson. Liverpool: Liverpool University Press.

Gordon, R. E. \& Mihm, J. M. (1957). A comparative study of some strains received as nocardiae. J Bacteriol 73, 15-27.

Gordon, R. E. \& Minm, J. M. (1962). The type species of the genus Nocardia. J Gen Microbiol 27, 1-10.

Gordon, R. E., Barnett, D. A., Handerhan, J. E. \& Pang, C. H.-N. (1974). Nocardia coeliaca, Nocardia autotrophica, and the nocardin strain. Int J Syst Bacteriol 24, 54-63.

Hayakawa, M. \& Nonomura, H. (1987). Humic acid-vitamin agar, a new medium for the selective isolation of soil actinomycetes. J Ferment Technol 65, 501-509.

Jiang, L. Y., Li, M. G., Li, W. J., Cui, X. L., Xu, L. H. \& Jiang, C. L. (2001). Study on the application of quantitative analysis of cell-wall amino acids in actinomycetes. Acta Microbiol Sin 41, 270-277.

Jones, K. L. (1949). Fresh isolates of actinomycetes in which the presence of sporogenous aerial mycelia is a fluctuating characteristic. J Bacteriol 57, 141-145.

Kageyama, A., Poonwan, N., Yazawa, K., Mikami, Y. \& Nishimura, K. (2004a). Nocardia asiatica sp. nov., isolated from patients with nocardiosis in Japan and clinical specimens from Thailand. Int J Syst Evol Microbiol 54, 125-130.

Kageyama, A., Yazawa, K., Nishimura, K. \& Mikami, Y. (2004b). Nocardia inohanensis sp. nov., Nocardia yamanashiensis sp. nov. and Nocardia niigatensis sp. nov., isolated from clinical specimens. Int J Syst Evol Microbiol 54, 563-569.

Kämpfer, P. \& Kroppenstedt, R. M. (1996). Numerical analysis of fatty acid patterns of coryneform bacteria and related taxa. Can J Microbiol 42, 989-1005.

Kämpfer, P., Buczolits, S., Jäckel, U., Grün-Wollny, I. \& Busse, H.-J. (2004). Nocardia tenerifensis sp. nov. Int J Syst Evol Microbiol 54, 381-383.

Kelly, K. L. (1964). Inter-Society Color Council - National Bureau of Standards Color-Name Charts Illustrated with Centroid Colors. Washington, DC: US Government Printing Office.

Kimura, M. (1980). A simple method for estimating evolutionary rates of base substitutions through comparative studies of nucleotide sequences. J Mol Evol 16, 111-120.

Kimura, M. (1983). The Neutral Theory of Molecular Evolution. Cambridge: Cambridge University Press.

Kumar, S., Tamura, K., Jakobsen, I. B. \& Nei, M. (2001). MEGA2: Molecular Evolutionary Genetics Analysis software. Bioinformatics 17, 1244-1245.

Lechevalier, M. P. (1976). The taxonomy of the genus Nocardia: some light at the end of the tunnel? In The Biology of the Nocardiae, pp. 1-33. Edited by M. Goodfellow, G. H. Brownell \& J. A. Serrano. London: Academic Press.

Lechevalier, M. P. \& Lechevalier, H. A. (1970). Chemical composition as a criterion in the classification of aerobic actinomycetes. Int $J$ Syst Bacteriol 20, 435-443.

Lechevalier, M. P. \& Lechevalier, H. A. (1980). The chemotaxonomy of actinomycetes. In Actinomycete Taxonomy, Special Publication no. 
6, pp. 227-291. Edited by A. Dietz \& J. Thayer. Arlington, VA: Society for Industrial Microbiology.

Lechevalier, M. P., De Bièvre, C. \& Lechevalier, H. A. (1977). Chemotaxonomy of aerobic actinomycetes: phospholipid composition. Biochem Syst Ecol 5, 249-260.

Lechevalier, M. P., Stern, A. E. \& Lechevalier, H. A. (1981). Phospholipids in the taxonomy of actinomycetes. Zentralbl Bakteriol Hyg Abt 1 Suppl 11, 111-116.

Maldonado, L., Hookey, J. V., Ward, A. C. \& Goodfellow, M. (2000). The Nocardia salmonicida clade, including descriptions of Nocardia cummidelens sp. nov., Nocardia fluminea sp. nov. and Nocardia soli sp. nov. Antonie van Leeuwenhoek 78, 367-377.

Mandel, M. \& Marmur, J. (1968). Use of ultraviolet absorbance temperature profile for determining the guanine plus cytosine content of DNA. Methods Enzymol 12B, 195-206.

Marmur, J. (1961). A procedure for the isolation of deoxyribonucleic acid from microorganisms. J Mol Biol 3, 208-218.

McNeil, M. M. \& Brown, J. M. (1994). The medically important aerobic actinomycetes: epidemiology and microbiology. Clin Microbiol Rev 7, 357-417.

Minnikin, D. E., Alshamaony, L. \& Goodfellow, M. (1975). Differentiation of Mycobacterium, Nocardia and related taxa by thin-layer chromatographic analysis of whole-organism methanolysates. J Gen Microbiol 88, 200-204.

Mordarska, H., Mordarski, M. \& Goodfellow, M. (1972). Chemotaxonomic characters and classification of some nocardioform bacteria. J Gen Microbiol 71, 77-86.

Orchard, V. A. \& Goodfellow, M. (1980). Numerical classification of some named strains of Nocardia asteroides and related isolates from soil. J Gen Microbiol 118, 295-312.

Orchard, V. A., Goodfellow, M. \& Williams, S. T. (1977). Selective isolation and occurrence of Nocardiae in soil. Soil Biol Biochem 9, 233-238.

Saintpierre-Bonaccio, D., Maldonado, L. A., Amir, H., Pineau, R. \& Goodfellow, M. (2004). Nocardia neocaledoniensis sp. nov., a novel actinomycete isolated from a New-Caledonian brown hypermagnesian ultramafic soil. Int J Syst Evol Microbiol 54, 599-603.

Saitou, N. \& Nei, M. (1987). The neighbor-joining method: a new method for reconstructing phylogenetic trees. Mol Biol Evol 4, 406-425.
Sasser, M. (1990). Identification of bacteria by gas chromatography of cellular fatty acids. USFCC Newsl 20, 1-6.

Shirling, E. B. \& Gottlieb, D. (1966). Methods for characterization of Streptomyces species. Int J Syst Bacteriol 16, 313-340.

Society for American Bacteriologists (1957). Manual of Microbiological Methods. New York: McGraw-Hill.

Stackebrandt, E., Rainey, F. A. \& Ward-Rainey, N. L. (1997). Proposal for a new hierarchic classification system, Actinobacteria classis nov. Int J Syst Bacteriol 47, 479-491.

Tatusova, T. A. \& Madden, T. L. (1999). BLAST 2 sequences - a new tool for comparing protein and nucleotide sequences. FEMS Microbiol Lett 174, 247-250.

Thompson, J. D., Gibson, T. J., Plewniak, F., Jeanmougin, F. \& Higgins, D. G. (1997). The CLUSTAL X Windows interface: flexible strategies for multiple sequence alignment aided by quality analysis tools. Nucleic Acids Res 25, 4876-4882.

Tsukamura, M. (1966). Adansonian classification of mycobacteria. J Gen Microbiol 45, 253-273.

Waksman, S. A. (1961). The Actinomycetes, vol. 2, Classification, Identification and Descriptions of Genera and Species. Baltimore: Williams \& Wilkins.

Wang, L., Zhang, Y., Lu, Z., Shi, Y., Liu, Z., Maldonado, L. \& Goodfellow, M. (2001). Nocardia beijingensis sp. nov., a novel isolate from soil. Int J Syst Evol Microbiol 51, 1783-1788.

Williams, S. T., Goodfellow, M., Alderson, G., Wellington, E. M. H., Sneath, P. H. A. \& Sackin, M. J. (1983). Numerical classification of Streptomyces and related genera. J Gen Microbiol 129, 1743-1813.

Xu, P., Li, W. J., Zhang, Y. G., Tang, S. K., Gao, H. Y., Xu, L. H., He, B. K. \& Jiang, C. L. (2003a). Molecular screening and distribution of polyketide antibiotics producers from Actinomycetes. J Chin Antibiot 28, 321-324.

Xu, P., Li, W. J., Xu, L. H. \& Jiang, C. L. (2003b). A microwave based method for genomic DNA extraction from actinomycetes. Microbiology 30, 82-84 (in Chinese).

Yassin, A. F., Rainey, A. F. \& Steiner, U. (2001). Nocardia cyriacigeorgici sp. nov. Int J Syst Evol Microbiol 51, 1419-1423.

Zhang, J. L., Liu, Z. \& Goodfellow, M. (2003). Nocardia caishijiensis sp. nov., a novel soil actinomycete. Int J Syst Evol Microbiol 53, 999-1004. 